\title{
EXAMINING THE MODUS OPERANDI OF SEXUAL OFFENDERS AGAINST CHILDREN AND ITS PRACTICAL IMPLICATIONS
}

\author{
Benoit Leclerc ${ }^{\mathrm{a},}{ }^{*}$, Jean Proulx ${ }^{\mathrm{b}}$, \& Eric Beauregard ${ }^{\mathrm{c}}$ \\ ${ }^{a}$ School of Criminology and Criminal Justice, Griffith University, Brisbane (Queensland) \\ 4111, Australia \\ ${ }^{b}$ School of Criminology, University of Montreal \& Research Centre Philippe-Pinel of \\ Montreal, 10905 boul. Henri-Bourassa est, Montreal, Quebec, Canada, H1C 1H1 \\ ${ }^{c}$ School of Criminology, Simon Fraser University, 8888 University Drive, Burnaby \\ (British Columbia) V5A $1 S 6$
}

* Corresponding author. Tel.: +61 737355823

E-mail address: benoitlec@hotmail.com b.leclerc@griffith.edu.au (B. Leclerc). 


\begin{abstract}
The aim of this article is to review the theoretical, empirical and practical implications related to the modus operandi of sexual offenders against children. First, the rational choice perspective in criminology, which emphasizes the decision-making of offenders, is presented. Second, the descriptive studies aimed specifically at providing information on modus operandi of sexual offenders against children are also presented. This is followed by research that investigates the links between the modus operandi of sexual offenders against children and various factors such as victim characteristics. Third, offenders' treatment as well as situational crime prevention implications in regards to modus operandi are discussed in order to highlight their respective potential for the prevention of child sexual abuse.
\end{abstract}

Keywords: Child sexual abuse, sexual offending, modus operandi, treatment, situational crime prevention. 


\section{INTRODUCTION}

In their empirical studies on sexual offenses against children, Kaufman, Hilliker and Daleiden (1996) define the modus operandi as "the pattern of behaviors that perpetrators display in the periods prior to, during, and following illicit sexual contact” (p.18). Another definition is provided by Douglas, Burgess, Burgess and Ressler (1997) who define modus operandi as "the actions taken by an offender to perpetrate the offense successfully” (p.353). Over the years, the interest regarding the study of the modus operandi of sexual offenders against children has increased. As an example, a series of modus operandi studies have been carried out by Kaufman and his colleagues (e.g. Kaufman, Hilliker and Daleiden, 1996) to provide empirical information for prevention purposes. Since the rational choice perspective in criminology focuses on the criminal decision-making in relation to crime commission (Cornish, 1993) which includes the strategies adopted by the offender, it represents a useful framework to better understand the modus operandi of offenders.

\section{THEORETICAL CONTEXT}

\section{THE RATIONAL CHOICE PERSPECTIVE IN CRIMINOLOGY}

The starting point of the rational choice perspective on criminal behavior is that criminal acts are never senseless but purposive (Cornish and Clarke, 1986; Clarke and Cornish, 2001). Offenders are seen as rational individuals who commit crimes in an attempt to satisfy their need for rewards such as money, sexual intercourse, elevated status, and excitement. Cornish and Clarke (2002) also state that "the choice of methods for carrying out the crime, and the decision-making involved, are also best regarded as 
instrumental behaviors in the service of offenders' goals” (p.41). Even though decisionmaking is constrained by time, the offender's cognitive abilities, and the availability of relevant information (Cornish and Clarke, 1987; see also Johnson and Payne, 1986), offenders nevertheless attempt to minimize their risks of apprehension and maximize their gains. Offenders are thus perceived as decision makers, whose choices are directed by the values, the costs, and the likelihood of obtaining desired outcomes. The rational choice perspective is particularly relevant since it "offers just such a fluid, dynamic picture - one that views offending as more present-oriented and situationally influenced" than other criminological theories (Cornish and Clarke, 2001, p.32). Situational factors such as the resistance of the victim are seen as having an important role since it influences the decisions of the offender and consequently, the offender-victim interaction that follows when a crime is committed (Tedeschi and Felson, 1994). For instance, Elliott, Browne and Kilcoyne (1995) found that 39\% of sexual offenders in their sample said that they would use threats or violence to overcome child resistance if necessary. Because crime is viewed as a dynamic process influenced by situational factors, offenders are seen as individuals that may improve their decision-making through experience and learn to modify their strategies to commit crimes.

An important feature of this perspective is that it emphasizes the importance of the behaviors adopted by the offender to more fully comprehend the "how" of the crime. From a rational choice perspective, Proulx, Ouimet and Lachaîne (1995) conducted an exploratory study analyzing the decisions and behaviors of sexual offenders against children to better understand their process of crime commission. They found that the offender has to make a series of choices before sexually abusing a child. First, the 
offender has to choose his hunting ground, that is, the places where he is likely to encounter a potential victim and the time when he is going to offend. Following these decisions, the offender has to select a victim according to his/her erotic value (age, gender and physical characteristics), to his/her vulnerability (physical and/or psychological) and to his/her familiarity. Finally, the offender has to decide how he is going to approach the victim and which strategy he will adopt to get the victim involved in sexual activity. But more importantly, this study suggested that the strategies adopted by a sexual offender are influenced by situational factors. For instance, it showed that a public hunting ground and a stranger victim are characteristics that may be related to using coercion for obtaining sexual contact. Ouimet and Proulx (1994) also suggested that the more distance traveled by the offender to find a potential victim, the higher the level of violence used to commit the crime.

\section{THE CRIME-COMMISSION MODEL IN CRIMINOLOGY}

The rational choice perspective was used as the theoretical framework to derive models of criminal behavior each implying a distinctive decision process influenced by a different set of factors (Clarke and Cornish, 1985; Clarke and Cornish, 2001; Cornish and Clarke, 1986). For the purpose of this article, the model of interest is the criminal event model which accounts for the commission of a specific crime. Because the initial criminal event model involved only one stage of the crime-commission process, that is, target selection, Cornish (1994) proposed the concept of crime scripts to assist in the analysis of the whole crime-commission process. Crime scripts are step-by-step accounts of the strategies adopted by offenders to commit crimes. The most important benefit of 
the crime script concept is that it provides a framework to systematically investigate all of the stages of the crime-commission process of a specific crime and in as much detail as existing data allow (Cornish, 1994). It also helps to identify the decisions that the offender must make at each stage as well as the situational variables such as obstacles that might lead the offender to alter his initial modus operandi.

Cornish (1998) was the first to elaborate crime-commission script models for sexual offenses against children. He outlined two particular scripts related to sexual abuse of male victims, that is, a script to account for offenses committed by stranger offenders in public places and another explaining offenses perpetrated by offenders in residential institutions. As an illustration, the latter script is the following: preparation (elaboration of sexual fantasies, access and use of child pornography, network of other offenders), entry to setting (already in setting), preconditions (using a legitimate role, right of access to all aspects of setting, absence of capable guardians), instrumental precondition (selecting a potential victim), instrumental initiation ("grooming”), instrumental actualization (removal or access to an unsupervised place, lack of escape routes), doing (sexual assault), postcondition (successful disengagement) and exit from setting. Although these crime-commission script models were not empirically verified, they showed the relevance of studying sexual offenses using this approach. Moreover, the crime-commission script model represents a sequence of instrumental actions prior, during, and following the criminal act and thus, is consistent with the modus operandi temporal framework provided by Kaufman, Hilliker and Daleiden (1996).

Somewhat influenced by Cornish’s work (1998), Beauregard, Proulx, Rossmo, Leclerc and Allaire (accepted for publication) conducted a study on serial sex offenders 
to identify particular crime-commission scripts with this population. This study analyzed 361 criminal events reported by 72 serial sex offenders, mostly offenders against women. Using hierarchical cluster and multiple correspondence analyses, the authors identified three different crime-commission scripts: (1) coercive; (2) manipulative; and (3) nonpersuasive, that is, no particular strategy. This study also suggests that sexual offenders can switch from one strategy to another according to environmental factors, such as the crime location, when committing crimes. The results of this study support the preliminary results obtained by Proulx et al. (1995).

\section{EMPIRICAL STUDIES}

The first studies which specifically analyzed the modus operandi of sexual offenders against children were conducted in the late 1980s (Berliner and Conte, 1990; Budin and Johnson, 1989; Christiansen and Blake, 1990; Conte, Wolf and Smith, 1989; Lang and Frenzel, 1988) (see Table I). These studies were mainly undertaken to provide information for prevention purposes. As Berliner and Conte (1990) pointed out: "Much current prevention knowledge is based on anecdotal information about the victimization process. Understanding the process... will help locate areas for prevention education both for already victimized children and for children in general” (p.29). These studies provided crucial data about the strategies adopted by sexual offenders against children to commit their crimes. For instance, offenders have been found to gradually desensitize the victim to physical contact before moving to sexual touch (Berliner and Conte, 1990; Christiansen and Blake, 1990). Offenders also use some type of coercion and threats (Berliner and Conte, 1990; Budin and Johnson, 1989; Conte et al., 1989; Lang and 
Frenzel, 1988), particularly when manipulation fails (Christiansen and Blake, 1990). These studies, however, did not define the concept of modus operandi and were lacking reliable instruments to assess all stages of modus operandi (e.g. gaining access to the victim, gaining the trust of the victim). Consequently, not all stages of the modus operandi could be systematically investigated and specific strategies at various stages of modus operandi could not be identified either.

INSERT TABLE I about here

An important contribution of the Modus Operandi Questionnaire (MOQ) developed by Kaufman (1991) is that it provides a temporal framework to collect data on all aspects of offender-victim interaction during the crime-commission process. This framework places behaviors along a temporal continuum beginning with offenders' tactics to access victims and includes strategies adopted to gain victims' trust, gain victims' cooperation in sexual activity, and maintain victims' silence following the abuse. With this instrument, Kaufman and his colleagues undertook a series of studies to examine the modus operandi of sexual offenders against children. Because of the inherent qualities of this instrument (e.g. good internal consistency of the scales, see Kaufman et al., 1997; Kaufman et al., 1998), other researchers also adopted this means to study modus operandi (Leclerc, Proulx and McKibben, 2005; Smallbone and Wortley, 2000). Although these later studies are of significant interest, the modus operandi alone does not fully explain the crime-commission process. Factors such as victim characteristics and situational variables may be related and may influence the modus operandi which may, in turn, have consequences on the outcome of the crime. 
Furthermore, as stated by rational choice theorists, especially by Cornish (1994), offenders can adapt themselves to particular factors such as situational variables, and they can learn and innovate by adopting new strategies when necessary (Lacoste and Tremblay, 2003). This makes the study of relationships between modus operandi and other factors necessary to understand the crime-commission process.

Some studies examined the relationship between modus operandi and other characteristics with multivariate analyses. In general, research on sexual offending has shown that the modus operandi may vary according to the offender's age, victim characteristics and situational factors.

\section{AGE OF THE OFFENDER}

As indicated in Table II, one such study was conducted by Kaufman et al. (1998). These authors compared the modus operandi of adolescent and adult offenders and found that the age of the offender (adolescent or adult) might be related to modus operandi. They found two important differences between adolescent and adult modus operandi. First, their results showed that adolescent, compared to adult offenders, adopted strategies more frequently to commit their crimes. Second, adolescents also reported having used violence more often than adult offenders. To explain these results, Kaufman et al. (1998) suggested that adult offenders benefit from a special status (e.g. social, parental) which does not requires them to adopt strategies as often as adolescent offenders. As stated by Kaufman, Orts et al. (1996), offenders may also progress developmentally from the use of coercive strategies to more sophisticated methods like manipulation. Victim 
characteristics such as the age, however, could have a more prominent impact on modus operandi.

\section{AGE OF THE VICTIM}

With a sample of 226 adult offenders, Leclerc, Carpentier and Proulx (2006) studied the impact of several factors, such as the age of the victim (0-13 years old), on the likelihood of adopting a manipulative, a coercive or a non-persuasive strategy to involve the victim in sexual activity. They found that adult offenders who sexually abuse older children were more likely to use a manipulative, rather than a non-persuasive strategy. In addition, Kaufman, Hilliker and Daleiden (1996) found that various manipulative and coercive strategies adopted by adolescent offenders vary as a function of the age of the victim. Using a sample of 179 adolescent offenders, these authors examined the relationship between the age of the youngest victim (0-3 years, 4-6 years, 7-9 years, 1012 years, 13-17 years) and several sets of strategies in different stages of the modus operandi. Except for the "using alcohol and drugs" set of strategies to gain the victim's cooperation for which the frequency of use followed a linear increase across all age groups, the frequency of use for other sets of strategies (giving gifts and giving love/attention to gain victim's trust, giving love/attention and threatening to alter victimoffender relationship to gain victim's cooperation, and threatening to withdraw benefits to maintain victim's silence) rose as the victim's age increased from birth (0-3 years) to middle childhood (4-9 years) and then decreased as the victim's age increased from middle childhood to adolescence (10-17 years). While the age of the victim has an 
impact on the modus operandi, research is not as conclusive as with the gender of the victim.

\section{GENDER OF THE VICTIM}

Studying the effects of the gender of the victim on modus operandi, Kaufman, Hilliker and Daleiden (1996) found that several sets of strategies (giving gifts and giving love/attention to gain the victim's trust, giving love/attention, threatening to harm the victim's friend and family and to alter the victim-offender relationship to gain the victim's cooperation, and threatening to physically harm and to withdraw benefits to maintain the victim's silence) were more frequently used by offenders who abused both male and female victims than offenders who abused only male or female victims. Consequently, adolescent offenders who do not show a preference for the gender of their victim might simply be repeat offenders who learned that adopting strategies better serves their goals. However, as suggested by the results obtained by Hunter, Hazelwood and Slesinger (2000), it is also possible that the effect of victim gender on modus operandi depends on other factors such as victim age group, and victim level of resistance.

\section{OFFENDER-VICTIM RELATIONSHIP}

Another important factor linked to the modus operandi is the offender-victim relationship (intrafamilial or extrafamilial). Kaufman, Hilliker and Daleiden (1996) studied the relationship between this variable and adolescent modus operandi. They found that offenders who primarily selected intrafamilial victims more frequently adopted strategies which consisted of giving gifts to gain the victim's trust, giving love/attention 
and threatening to alter the victim-offender relationship to gain the victim's cooperation, and threatening to withdraw benefits to maintain the victim's silence than those primarily selecting extrafamilial victims. In another study, Kaufman et al. (1998) examined the impact of the offender-victim relationship on both adolescent and adult modus operandi. Specifically, they found that adolescent intrafamilial offenders adopted strategies consisting of exposing victims to pornography to gain their cooperation more frequently than adolescent extrafamilial offenders. Furthermore, in order to gain the victim's cooperation, intrafamilial offenders adopted strategies which consisted of giving gifts and making the victim feel helpless (e.g. tell others about their sexual behavior) more frequently than extrafamilial offenders, whereas the latter group more frequently used alcohol and drugs strategies. This was the case for both adolescent and adult offenders. These results show that intrafamilial offenders may benefit from their status as a family member in that it provides them the opportunity to command authority and thus, makes the adoption of particular strategies possible (e.g. tell others about their sexual behavior) (Kaufman et al., 1998).

\section{DEVIANT SEXUAL FANTASIES}

The presence of deviant sexual fantasies is also a relevant factor regarding modus operandi. Leclerc et al. (2006) found that adult offenders with deviant sexual fantasies 48 hours prior to their offense were significantly more likely to adopt a manipulative, rather than a non-persuasive strategy. It should be noted that adult offenders who adopted a manipulative strategy also had more deviant sexual fantasies than those who used a coercive strategy. This is somewhat inconsistent with results obtained by Carter, 
Kaufman, Barber, Galindo and Marnane (2002). Using a sample of 247 adolescent offenders, these authors specifically studied the relationship between sexual fantasies and violence, and they found that offenders who used extreme violence were those who reported a higher frequency of deviant sexual fantasies. However, they also found that adolescent offenders who used violence were more likely to report a higher frequency of sexual fantasies overall, that is, non deviant as well as deviant sexual fantasies. Adolescence is characterized "by an increase in sexual drive, with a concomitant increase in sexual interaction and experimentation... The increase of activity and interest in sexual behaviors are normal processes of the adolescent stage of human development” (Abel, Osborn and Twigg, 1990, p. 105). In contrast to most adult offenders, adolescents may not yet have developed a fixed pattern of sexual arousal and interest, and generally, low correspondence between measured arousal patterns and sexual offending history is found (Hunter and Becker, 1994; Hunter, Goodwin and Becker, 1994). Specifically, it suggests that the role of sexual fantasies in adolescent sexual offenses should be interpreted more cautiously.

Links between specific types of fantasies and various modus operandi strategies (giving drug/alcohol, desensitizing the victim to sexual contact, giving gifts, giving/withdrawing benefits) were recently examined (Carter, Kaufman, Estes and Stotler-Turner, 2005). A relationship was found, that is, between coercive sexual fantasies and drug/alcohol use for adult offenders. However, fantasies did not predict the preferred type of modus operandi in adolescent sexual offenses. Overall, previous studies show the complexity of the relationship between sexual fantasies and modus operandi. 
More importantly, it indicates that other research must be conducted to allow for more conclusive results.

INSERT TABLE II about here

\section{THE BENEFITS OF MODUS OPERANDI STUDIES}

\section{TREATMENT IMPLICATIONS OF MODUS OPERANDI STUDIES}

Across all modus operandi stages, offenders can adopt certain strategies that are similar to prosocial behaviors which consist of demonstrating love, attention and appreciation towards someone. For instance, in order to gain the trust of his victims, the offender can spend a lot of time with them, give them a lot of attention, play with them and/or take them places. To gain the cooperation of his victims in sexual activity, the offender can gradually desensitize them by non-sexual touching and/or saying loving things to them. In relapse prevention treatment, these behaviors are important links in the offense chain which leads to re-offending. Consequently, these strategies should be investigated in depth by therapists when assessing and treating offenders. As Kaufman et al. (1998) state, increased information regarding specific offender behavior patterns could help therapists emphasize these behaviors in the assessment process, and assist offenders to recognize them so as to prevent themselves from re-offending. This could allow offenders to interrupt their offense chain at an earlier, less dangerous point (Kaufman, Hilliker, Lathrop, Daleiden and Rudy, 1996). This is consistent with Cornish's (1994) rationale that the investigation of all stages of the crime-commission process provide a wide range of intervention points at which the crime could be disrupted before occurring. 
In relapse prevention treatment, detailed information about modus operandi can also be used as a framework to investigate obstacles that prevented offenders from committing crimes in particular modus operandi stages. For instance, an offender may not be capable of obtaining time alone with a child too well supervised by his parents or may be less able to gain the cooperation of a child by desensitizing him to sexual contact in the absence of pornographic materials. Therapists could emphasize those obstacles (e.g. presence of someone who might interfere, no access to pornographic material) encountered in specific modus operandi stages to more fully understand exactly how these offenders were stopped from offending and why they did so. It would provides a fuller picture of offenders' crime-commission process to therapists as well as a means to identify where the crime-commission process is more likely to fail in order to favor the establishment of particular conditions which render child sexual abuse less possible in the immediate environment of offenders (e.g. not being alone with children, not having access to pornographic materials).

Detailed information on the modus operandi of sexual offenders against children also has implications for the treatment of child sexual abuse victims. With this information, therapists working with victims could have access to strategies adopted across all modus operandi stages. This way, victims would be more able to understand the crime-commission process of sexual offenses against children as well as to distinguish manipulative strategies from similar behaviors with a more prosocial intent. This would also help victims understand that they were not responsible for the sexual abuse (Kaufman et al., 1998). Further, victim information on victimization process and/or offender's self-report detailed modus operandi could help victim's therapists guide 
each victim to pinpoint particular events in which the offender stopped from abusing him/her. This information could provide cues on strategies that victims might be able to use to prevent further victimization. As Berliner and Conte (1990) have pointed out, children who have already been abused may be particular good candidates to benefit from information on victimization process. These children, having been through such a process, might be better able to use this knowledge to prevent further victimization. Berliner and Conte (1990) have already suggested that providing these children with a framework to better understand offenders' behaviors may make the assimilation of the information easier. It should be noted that because of their young age (victims of child sexual abuse are often vulnerable children, that is, needy and isolated children) (e.g. Elliott et al., 1995), the responsibility to prevent victimization by understanding offenders' strategies should not rest solely on the victims but also on their parents. Parents should be more able to understand offenders' strategies than the victims and to use this information to prevent child sexual abuse as well. In this sense, victim's parents can play an active role in the prevention of further victimization and they could be an integrate part in the treatment of child sexual abuse victims.

\section{SITUATIONAL CRIME PREVENTION IMPLICATIONS OF MODUS OPERANDI STUDIES}

Since situational crime prevention is a relatively new applied criminological model, key elements will be briefly reviewed before discussing its implications in regards to the modus operandi adopted by offenders in cases of child sexual abuse. Developed within an overall rational choice framework, situational crime prevention implies that 
crime can be conceived as being the outcome of immediate choices and decisions made by the offender (Clarke, 1980). The main goal of situational prevention is to make the offender change his mind from committing a crime by targeting the "precriminal situation” and reducing crime opportunities (Cusson, 1992; Cusson, Tremblay, L.-Biron, Ouimet and Grandmaison, 1994). Situational crime prevention consists of "opportunityreducing measures that (1) are directed at highly specific forms of crime, (2) involve the management, design or manipulation of the immediate environment in as systematic and permanent way as possible, (3) make crime more difficult and risky, or less rewarding and excusable...” (Clarke, 1997, p.4). More recently, Wortley (1997; 1998; 2001) has argued that opportunity reduction is only half of situational crime prevention and proposed (2001) a classification of strategies and techniques for controlling situational precipitators of crime that complement Clarke's (1997) existing classification of opportunity-reduction strategies. Techniques aimed at controlling precipitators of crime are directed at the motivational side of the person-situation interaction rather than the opportunity side (e.g. reducing permissibility by "shoplifting is stealing” signs). Based on Wortley's work, Cornish and Clarke (2003) proposed a revised classification of situational prevention strategies. Examples of situational prevention techniques include the introduction of baggage and passenger screening in airports, the installation of silent alarms in victims' homes, the development of security-coded car radios and the promotion of responsible drinking practices (Clarke, 1997).

Situational crime prevention also benefited from Cornish's work, which, as previously mentioned, resulted in the development of crime-commission script model analysis (Cornish, 1994). In fact, providing a framework to investigate all stages of the 
crime-commission process of particular crimes offers a way of matching situational interventions to each of those stages (Cornish, 1994; 1998). With a fuller range of possible intervention-points, it also becomes possible to disrupt the perpetration of crime at an earlier point in the process (e.g. preparation phase). Crime-commission script models also offer a means to pinpoint particular stages in which obstacles (e.g. resistance of the victim, presence of someone who might interfere) may be most likely to stop the offender in his process of committing a crime. This can provide a fuller picture of the crime-commission process as well as a better understanding for situational prevention purposes.

Although the great importance of modus operandi information for situational prevention purposes has been emphasized earlier in criminology by Cornish, few researchers and clinicians who work with sexual offenders actually made suggestions as to possible situational prevention techniques based on offenders' strategies. This is not surprising since situational crime prevention has not been applied to sexual offenses against children. As Wortley and Smallbone (2006) puts it, it may be because sexual offending has often been conceived as the product of irrational and pathological individuals which guided researchers and clinicians to focus most of their work on the "individual" rather than on situational factors. It may be also due to the lack of studies aimed at linking the modus operandi of sexual offenders to other components of the crime such as situational factors. However, as suggested by recent studies (Kaufman, Mosher, Carter and Estes, 2006; Wortley and Smallbone, 2006), situational prevention of sexual offenses against children is possible and provides another means to prevent these offenses from occurring. Although speculative, suggestions of situational prevention 
have been made in regards to the modus operandi of sexual offenders against children and related factors such as the location of the crime.

Drawing on the general situational crime prevention strategies (Cornish and Clarke, 2003; Wortley, 2001), Wortley and Smallbone (2006) made suggestions by concentrating on four techniques, that is, increasing effort, increasing risk, controlling prompts and reducing permissibility. Increasing effort essentially means making it more difficult for offenders to commit their crimes. Wortley and Smallbone (2006) suggest that this may be achieved through excluding potential offenders from places where children are located such as youth-oriented organizations. Systematically screening employees and volunteers to prevent individuals with previous convictions for sexual offenses from working with children can be useful. However, given that other studies have found that too many sexual offenders against children do not have a previous sexual offense conviction (Leclerc et al., 2006; Smallbone and Wortley, 2000), it could also be relevant to screen the individual's behaviors with children, his motives as well as his previous work experience with children (Leclerc et al., 2005; Sullivan and Beech, 2004). For instance, Leclerc et al. (2005) found that the modus operandi of these offenders focus on spending a lot of time and being "overly touchy and affectionate" with potential victims (see also Sullivan and Beech, 2002). Organizations could verify if the candidates like to be in the company of children in a peculiar way, such as spending all their leisure time with children, for instance at break times, instead of mingling with the other employees. To avoid mistakenly excluding persons who are not sexual offenders, information about candidates should be first used as warning signs for further investigation (Leclerc et al., 2005; van Dam, 2001). Finally, on the basis that many 
sexual offenders against children also commit non-sexual offenses (e.g. Lussier, 2005; Smallbone and Wortley, 2000), Simon and Zgoba (2006) even suggested to screen individuals working with children for general criminality.

A specific type of intervention strategy aimed at increasing effort is controlling the facilitators of crime (e.g. weapons). In the case of sexual offending against children, pornography represents a possible strategy and a facilitator for offenders to commit their crimes (Elliott et al., 1995; Lang and Frenzel, 1988; Langevin and Curnoe, 2004; Smallbone and Wortley, 2000). The highest percentage of sexual offenders against children using this strategy was reported by Elliott et al. (1995) who indicated that $21 \%$ of their sample did so. Disrupting preparation and manipulation by a more restricted access to pornography is an interesting avenue to control this facilitator (Cornish, 1998). Furthermore, because many sexual offenses against children are committed by adolescent offenders (Barbaree, Hudson and Seto, 1993), this strategy would suggest that parents should themselves look into restricting their children's access to pornography (e.g. pornographic movies or magazines), if they are using any. This is even more important since adolescent offenders usually abuse their own relatives (Barbaree et al., 1993) and if pornography is available in home, it can facilitate the commission of the sexual offense.

Increasing risk refers to making the offender more likely to be observed or detected when committing a crime. Wortley and Smallbone (2006) suggest that the behavior of employees and volunteers working with children should be supervised and that supervision procedures governing the interaction with children should also be considered. They pointed out that procedures forbidding an employee/volunteer to be alone with a child (e.g. forbid sports coaches to go to competitions or on trips alone with 
a group of children) may be appropriate as well as physical modifications of the environment (e.g. glass panels in the doors) to increase natural surveillance (see also Leclerc et al., 2005). These procedures could make offenders’ modus operandi more observable or detectable and thus, increase offenders’ risks of apprehension.

Wortley and Smallbone (2006) also suggest that parents/caregivers can be better educated through public education programs to recognize danger signals such as offender modus operandi used to seek opportunities to be alone with a child. Wortley and Smallbone also state that those in charge of security in public locations, such as shopping malls, need to be aware of offender modus operandi and look out for suspicious behavior. This latter suggestion means that more capable guardianship, that is, individuals who are able to protect children by being aware of offenders' modus operandi, could also be extended to public locations in which many opportunities of encountering children exist such as parks, video arcades and playgrounds (Leclerc et al., 2006). Even if most sexual offenses against children tend to occur in private spaces (e.g. offender's home, victim's home), public places are still common locations where offenders can take their victims for sexual contact and they are still used by extrafamilial offenders to target and find potential victims (Elliott et al., 1995; Smallbone and Wortley, 2000). To increase risks for sexual offenders, physical modifications could also be considered in public locations such as shopping malls (e.g. public toilets designed where maximum advantage of natural surveillance is possible, especially in busy locations) (Wortley and Smallbone, 2006).

Controlling prompts involves identifying and removing situational triggers. This technique is directed at automatic or reflex responses (physiological or behavioral responses) to environmental conditions (e.g. viewing erotic images produces sexual 
arousal) (Wortley, 2001). For instance, the observation of children in 'provocative' situations (from the offender's perspective) may trigger offending (Wortley and Smallbone, 2006). Young (1997) found that routine activities are crucial in the sexual exploitation of children. After gaining the trust of parents and having access to their child, extrafamilial offenders can benefit from a routine relationship with the child that includes many of the same rights, privileges and responsibilities as family members. Giving the child a bath or tucking him into bed represents rights and responsibilities that may stimulate offending. Moreover, Wortley and Smallbone (2006) found that sexual offending often occurs while the offender is engaged in such intimate activities with the child. However, as these authors pointed out, controlling these triggers is very difficult. They go on to argue that parents should be careful as to whom they delegate these intimate tasks. They also suggest that by being able to better understand their crimecommission process during therapy, offenders should be more likely to avoid placing themselves in such high-risk situations.

Reducing permissibility refers to distorting moral reasoning processes so as to permit individuals to engage in normally proscribed behavior. It is based on the premise that "The human conscience is highly malleable and sensitive to the physical and social context in which behaviour is performed" (Wortley, 2001, p.70). For instance, based on the result that offenders frequently adopt the strategy consisting of watching TV with their victim in order to obtain time alone for sexual contact, Wortley and Smallbone (2006) suggest that this situation could provide an opportunity to target offenders' cognitions by messages through public education programs before the commission of the offense. Wortley and Smallbone state that these messages could challenge cognitive 
distortions such as 'I was teaching the child about sexuality' by setting out the harm and the consequences of child sexual abuse (see also Simon and Zgoba, 2006).

Wortley and Smallbone (2006) also suggest strategies aimed at challenging offenders' cognitions in youth-oriented organizations. One such strategy is introducing explicit codes of conduct and induction procedures for staff that clearly mention acceptable and unacceptable behavior. Other strategies involve providing formal opportunities for children to make complaints if abuse occurs (or if abuse is suspected to be in the process of being committed) and introducing a process of regular independent inspections within these organizations. These last two strategies might be especially valuable alternatives if introducing explicit codes of conduct and induction procedures are not appropriately followed by staff members.

While some situational prevention strategies have been suggested, Kaufman et al. (2006) recently proposed a situational prevention model to prevent sexual offending against children. This model is adapted from the work of Clarke (1995; 1997) in situational crime prevention and applied to child sexual abuse in which research on offenders' modus operandi is integrated. At the heart of this model is the "Crime Opportunity Structure” which consists of three components, that is, victim characteristics or situation (e.g. isolated, needy children, children lacking supervision), locations (e.g. parks, offender's home, youth-oriented organizations), and the facilitators of crime which basically refers to offender modus operandi strategies (e.g. desensitization to sexual contact, threats, coercion). These components interact with each other to create opportunities for sexual offending against children. This opportunity structure is itself 
influenced by factors such as lifestyle and routine activities, physical environment and offender characteristics.

Although new and needing further examination and testing, the situational prevention model offers a promising approach in the prevention of sexual offending against children. It illustrates that offender modus operandi is related to victim characteristics and locations, and more indirectly to other components such as lifestyle and routine activities, physical environment, and offender characteristics. This is of particular relevance since the modus operandi of sexual offenders against children is usually based on manipulation and establishing an intimate relationship with a vulnerable child who does not quite understand what is happening when sexual contacts are introduced in the relationship. In that sense, sexual offending against children is more difficult to observe and detect than most crimes. Consequently, it renders other crime components such as victim characteristics and locations as well as the understanding of the dynamic interplay between those components and the modus operandi, of extreme value to design prevention strategies. In other words, it basically suggests that the situational prevention model and particularly, the crime opportunity structure must be taken as a whole if successful situational prevention techniques are to be expected.

\section{CONCLUSION}

The overall purpose of modus operandi studies has always been to provide information to ultimately prevent sexual offenses against children. Descriptive studies on the modus operandi of sexual offenders against children initially showed how the behaviors adopted by offenders to commit their crimes can be sophisticated. These 
studies found that offenders adopt a variety of strategies to attain sub-goals (e.g. gaining victims' access, trust, cooperation in sexual activity, and maintaining victims' silence following the abuse) which enables them to perpetrate their offense successfully. A particularly consistent finding was that many offenders gradually desensitized their victim to physical contact before moving to sexual touch (Berliner and Conte, 1990; Christiansen and Blake, 1990). Although these descriptive studies are of significant interest, the modus operandi alone cannot explain the whole crime-commission process. As a result, some studies were conducted to examine the relationships between modus operandi and other characteristics such as victim and situational factors. Specifically, research showed that the modus operandi may be particularly influenced by the age and the gender of the victim as well as the offender-victim relationship and the presence of deviant sexual fantasies before the crime.

Modus operandi studies must be taken into account for the prevention of sexual offending against children. Offender modus operandi information is already used in relapse prevention treatment to prevent recidivism, but more detailed and specific information is needed to better assist offenders from re-offending. Moreover, a relatively new approach to control crime, situational crime prevention, was demonstrated to be successful with a variety of crimes (Clarke, 1997). From the model elaborated by Clarke (1995; 1997), Kaufman et al. (2006) proposed a model which integrates offender modus operandi information as central to understand child sexual abuse opportunities. This model has enormous potential and represents an innovative way to address and perhaps to reduce the number of children who are victims of sexual offenses. 
However, more offender modus operandi research is preferable before actually designing and applying situational prevention techniques to reduce the number of children victims of sexual offenses. Even though research on the modus operandi of sexual offenders against children has found existing relationships between modus operandi and characteristics such as victim and situational factors, more studies needs to be conducted to support actual results and to clarify certain relationships. Furthermore, other situational factors should be integrated in future research. For instance, understanding locations of sexual offenses against children (domestic, institutional, public) has shown to be promising for prevention initiatives (Wortley and Smallbone, 2006). Therefore, it would be interesting to examine the relationship between offender modus operandi and the location where the sexual episodes take place.

As previously mentioned, a better understanding of the dynamic interplay between the various components of the crime is also needed. The sexual offense itself which is the sexual behaviors adopted by the offender and the victim is another component worthy of attention. A rational choice approach implies that the modus operandi has a purpose, that some sexual offenders are more successful in their crimes and that most offenders would seek to employ those strategies that they have found to be successful in past sexual episodes. It can also be expected that those individuals who, as adolescents, were quite successful in their sexual offenses, would be more likely to reoffend in adulthood. In this sense, it also appears relevant to conduct studies to verify if offender modus operandi determines or tailors the sexual behaviors adopted by the offender and the victim in sexual episodes. It follows that it would be necessary to examine if victim characteristics and situational factors condition the impact of offender 
modus operandi on sexual behaviors. For instance, because male victims have been found to participate more in sexual activity than female victims (Erickson, Walbeck and Seely, 1988; Proulx, Perreault, Ouimet and Guay, 1999), one might examine if the impact of offender modus operandi on sexual behaviors adopted by the offender and the victim is mediated by the gender of the victim. The idea of the above suggestions for future studies is ultimately to nourish crime prevention initiatives. 


\section{REFERENCES}

Abel, G. G., Osborn, C. A. and Twigg, D. A. (1993). Sexual assault through the life span: Adult offenders with juvenile histories. In H. E. Barbaree, W. L. Marshall and S. M. Hudson (Eds.), The Juvenile Sex Offender (pp. 105-117). New York, NY: Guilford Press.

Barbaree, H. E., Hudson, S. M. and Seto, M. C. (1993). Sexual assault in society: The role of the juvenile offender. In H. E. Barbaree, W. L. Marshall and S. M. Hudson (Eds.), The Juvenile Sex Offender (pp. 1-24). New York, NY: Guilford Press.

Beauregard, E., Proulx, J., Rossmo, D. K., Leclerc, B. and Allaire, J. F. (accepted for publication). A script analysis of patterns in the hunting process of serial sex offenders. Criminal Justice and Behavior.

Berliner, L. and Conte, J. R. (1990). The process of victimization: The victim's perspective. Child Abuse and Neglect, 14, 29-40.

Budin, L. E. and Johnson, C. F. (1989). Sex abuse prevention programs: Offenders' attitudes about their efficacy. Child Abuse and Neglect, 13, 77-87.

Carter, M., Kaufman, K. L., Barber, M., Galindo, R. and Marnane, J. (2002, october). The relationships between sex offenders' sexual fantasies, sexual histories and modus operandi. Paper presented at the 21th Annual Conference of the Association for the Treatment of Sexual Abusers, Chicago, IL.

Carter, M., Kaufman, K. L., Estes, L. and Stotler-Turner, E. (2005, november). Ain't nothing like the real thing: Sexual fantasy and modus operandi in adult and juvenile sex offenders. Paper presented at the 24th Annual Conference of the Association for the Treatment of Sexual Abusers, Salt Lake City, Utah. 
Christiansen, J. R. and Blake, R. H. (1990). The grooming process in father-daughter incest. In A. L. Horton, B. L. Johnson, L. M. Rowndy and D. Williams (Eds.), The incest perpetrator: A family member no one wants to treat (pp. 88-98). Sage Publications.

Clarke, R. V. (1980). 'Situational”' crime prevention: Theory and practice. British Journal of Criminology, 20, 136-147.

Clarke, R. V. (1995). Situational crime prevention. In M. Tonry and D. Farrington (Eds.), Building a safer society: Strategic approaches to crime prevention (pp. 91150). Crime and Justice: An Annual Review of Research. Vol. 19. Chicago: University of Chicago Press.

Clarke, R. V. (1997). Introduction. In R. V. Clarke (Ed.), Situational crime prevention: Successful case studies (pp. 1-43). Guilderland, NY: Harrow and Heston.

Clarke, R. V. and Cornish, D. B. (1985). Modeling offenders' decisions: A framework for research and policy. In M. Tonry and N. Morris (Eds.), Crime and Justice: An Annual Review of Research (pp. 147-185). Vol. 6. Chicago: University of Chicago Press.

Clarke, R. V. and Cornish, D. B. (2001). Rational choice. In R. Paternoster and R. Bachman (Eds.), Explaining criminals and crime: Essays in contemporary criminological theory (pp. 23-42). Roxbury Publishing Company.

Conte, J. R., Wolf, S. and Smith, T. (1989). What sexual offenders tell us about prevention strategies. Child Abuse and Neglect, 13, 293-301.

Cornish, D. B. (1993). Theories of action in criminology: Learning theory and rational choice approaches. In R. V. Clarke \& M. Felson (Eds.), Routine activity and 
rational choice (pp.351-382). Advances in Criminological Theory. Vol. 5. New Brunswick, New Jersey: Transaction Publishers.

Cornish, D. B. (1994). The procedural analysis of offending and its relevance for situational prevention. In R. V. Clarke (Ed.), Crime Prevention Studies (pp. 151196), Vol. 3. Monsey, N.Y.: Criminal Justice Press.

Cornish, D. B. (1998). Regulating lifestyles: A rational choice perspective. Paper presented at the $7^{\text {th }}$ International Seminar on Environmental Criminology and Crime Analysis, Barcelona.

Cornish, D. B. and Clarke, R. V. (1986). Introduction. In D. B. Cornish and R. V. Clarke (Eds.), The reasoning criminal: Rational choice perspectives on offending (pp. 1-16). New York: Springer-Verlag.

Cornish, D. B. and Clarke, R. V. (1987). Understanding crime displacement: An application of rational choice theory. Criminology, 25, 933-947.

Cornish, D. B. and Clarke, R. V. (2002). Analyzing organized crimes. In A. R. Piquero and S. G. Tibbetts (Eds.), Rational choice and criminal behavior: Recent research and future challenges (pp. 41-63). New York: Routledge.

Cornish, D. B. and Clarke, R. V. (2003). Opportunities, precipitators and criminal decisions: A reply to Wortley's critique of situational crime prevention. In M. J. Smith and D. B. Cornish (Eds.), Theory for practice in situational crime prevention (pp. 41-96). Crime Prevention Studies. Vol. 16. Monsey, N.Y.: Criminal Justice Press.

Cusson, M. (1992). L’analyse criminologique et la prévention situationnelle. Revue Internationale de Criminologie et de Police Technique, 2, 137-149. 
Cusson, M., Tremblay, P., L.-Biron, L., Ouimet, M. and Grandmaison, R. (1994). La planification et l'évaluation de projets en prévention du crime. Rapport de recherche, Gouvernement du Québec, Ministère de la Sécurité publique. Direction générale de la sécurité et de la prévention.

Douglas, J. E., Burgess, A. W., Burgess, A. G. and Ressler, R. K. (1997). Crime Classification Manual. San Francisco, Jossey-Bass Publishers.

Elliott, M., Browne, K. and Kilcoyne, J. (1995). Child sexual abuse prevention: What offenders tell us. Child Abuse and Neglect, 19, 579-594.

Erickson, W. D., Walbeck, N. H. and Seely, R. K. (1988). Behavior patterns of child molesters. Archives of Sexual Behavior, 17, 77-87.

Hunter, J. A. and Becker, J. V. (1994). The role of deviant sexual arousal in juvenile sexual offending. Etiology, evaluation, and treatment. Criminal Justice and Behavior, 21, 132-149.

Hunter, J. A., Goodwin, D. W. and Becker, J. V. (1994). The relationship between phallometrically measured deviant sexual arousal and clinical characteristics in juvenile sexual offenders. Behavior, Research and Therapy, 32, 533-538.

Hunter, J. A., Hazelwood, R. R. and Slesinger, D. (2000). Juvenile-perpetrated sex crimes: Patterns of offending and predictors of violence. Journal of Family Violence, 15, 81-93.

Johnson, E. and Payne, J. (1986). The decision to commit a crime: An informationprocessing analysis. In D. B. Cornish and R. V. Clarke (Eds.), The reasoning criminal: Rational choice perspectives on offending (pp. 170-185). New York: Springer-Verlag. 
Kaufman, K. L. (1991). Modus Operandi Questionnaire. Columbus, OH: Author (Children’s Hospital).

Kaufman, K. L., Hilliker, D. R. and Daleiden, E. L. (1996). Subgroup differences in the modus operandi of adolescent sexual offenders. Child Maltreatment, 1, 17-24.

Kaufman, K. L., Hilliker, D. R., Lathrop, P., Daleiden, E. L. and Rudy, L. (1996). Sexual Offenders' Modus Operandi. A Comparison of Structured Interview and Questionnaire Approaches. Journal of Interpersonal Violence, 11, 19-34.

Kaufman, K. L., Holmberg, J. K., Orts, K. A., McCrady, F. E., Rotzien, A. L., Daleiden, E. L. et al. (1998). Factors influencing sexual offenders' modus operandi: An examination of victim-offender relatedness and age. Child Maltreatment, 3, 349361.

Kaufman, K. L., McCrady, F. E., Holmberg, J. K., Rotzien, A. L., Orts, K. A., Hilliker, D. R. et al. (1997, october). Factor structure of the behaviors of sexual offenders as measured by the modus operandi questionnaire. Paper presented at the 16th Annual Conference of the Association for the Treatment of Sexual Abusers, Arlington, V.A.

Kaufman, K. L., Mosher, H., Carter, M. and Estes, L. (2006). An empirically based situational prevention model for child sexual abuse. In R. Wortley and S. Smallbone (Eds.), Situational prevention of child sexual abuse (pp. 101-144). Crime Prevention Studies. Vol. 19. Monsey, N.Y.: Criminal Justice Press.

Kaufman, K. L., Orts, K., Holmberg, J., McCrady, F., Daleiden, E. L. and Hilliker, D. (1996, november). Contrasting adult and adolescent sexual offenders' modus 
operandi: A developmental process? Paper presented at the 15th Annual Conference of the Association for the Treatment of Sexual Abusers, Chicago, IL.

Kaufman, K. L., Wallace, A. M., Johnson, C. F. and Reeder, M. L. (1995). Comparing female and male perpetrators' modus operandi. Victims' reports of sexual abuse. Journal of Interpersonal Violence, 10, 322-333.

Lacoste, J. and Tremblay, P. (2003). Crime and innovation: A script analysis of patterns in check forgery. In M. J. Smith and D. B. Cornish (Eds.), Theory for practice in situational crime prevention (pp. 169-196). Crime Prevention Studies. Vol. 16. Monsey, N.Y.: Criminal Justice Press.

Lang, R. A. and Frenzel, R. R. (1988). How sexual offenders lure children. Annals of Sex Research, 1, 303-317.

Langevin, R. and Curnoe, S. (2004). The use of pornography during the commission of sexual offenses. International Journal of Offender Therapy and Comparative Criminology, 48, 572-586.

Leclerc, B., Carpentier, J. and Proulx, J. (2006). Strategies adopted by sexual offenders to involve children in sexual activity. In R. Wortley and S. Smallbone (Eds.), Situational prevention of child sexual abuse (pp. 251-270). Crime Prevention Studies. Vol. 19. Monsey, N.Y.: Criminal Justice Press.

Leclerc, B., Proulx, J. and McKibben, A. (2005). Modus operandi of sexual offenders working or doing voluntary work with children and adolescents. Journal of Sexual Aggression, 2, 187-195. 
Lussier, P. (2005). The criminal activity of sexual offenders in adulthood: Revisiting the specialization debate. Sexual Abuse: A Journal of Research and Treatment, 17, 269-292.

Ouimet, M. and Proulx, J. (1994, november). Spatial and temporal behavior of pedophiles: Their clinical usefulness as to the relapse prevention model. Paper presented at the 46th Annual Conference of the American Society of Criminology, Miami, FL.

Proulx, J., Ouimet, M. and Lachaîne, N. (1995). C Criminologie de l’acte et pédophilie. Revue Internationale de Criminologie et de Police Technique, 48, 294-310.

Proulx, J., Perreault, C., Ouimet, M. and Guay, J. P. (1999). Les agresseurs sexuels d'enfants: scénarios délictuels et troubles de la personnalité. In J. Proulx, M. Cusson and M. Ouimet (Eds.), Les violences criminelles (pp. 187-216). Les Presses de l'Université Laval.

Simon, L. M. J. and Zgoba, K. (2006). Sex crimes against children: Legislation, prevention and investigation. In R. Wortley and S. Smallbone (Eds.), Situational prevention of child sexual abuse (pp. 65-100). Crime Prevention Studies. Vol. 19. Monsey, N.Y.: Criminal Justice Press.

Smallbone, S. and Wortley, R. (2000). Child sexual abuse in Queensland: Offender characteristics and modus operandi (Full report). Brisbane, Australia: Queensland Crime Commission.

Sullivan, J. and Beech, A. (2002). Professional perpetrators: Sex offenders who use their employment to target and sexually abuse the children with whom they work. Child Abuse Review, 11, 153-167. 
Sullivan, J. and Beech, A. (2004). A comparative study of demographic data relating to intra- and extra-familial child sexual abusers and professional perpetrators. Journal of Sexual Aggression, 10, 39-50.

Tedeschi, J. T. and Felson, R. B. (1994). Violence, aggression, and coercive actions. Washington, DC: American Psychological Association.

van Dam, C. (1996). How child sexual molesters groom adults to gain access to children. Doctoral dissertation. Cincinnati, OH: The Union Institute.

van Dam, C. (2001). Identifying child molesters: Preventing child sexual abuse by recognizing the patterns of the offenders. The Haworth Press.

Wortley, R. (1997). Reconsidering the role of opportunity in situational crime prevention. In G. Newman, R. V. Clarke and S. G. Shoham (Eds.), Rational choice and situational crime prevention: Theoretical foundations (pp. 65-81). Dartmouth, UK: Ashgate Publishing Company.

Wortley, R. (1998). A two-stage model of situational crime prevention. Studies on Crime and Crime Prevention, 7, 173-188.

Wortley, R. (2001). A classification of techniques for controlling situational precipitators of crime. Security Journal, 14, 63-82.

Wortley, R. and Smallbone, S. (2006). Applying situational principles to sexual offenses against children. In R. Wortley and S. Smallbone (Eds.), Situational prevention of child sexual abuse (pp. 7-35). Crime Prevention Studies. Vol. 19. Monsey, N.Y.: Criminal Justice Press. 
Young, S. (1997). The use of normalization as a strategy in the sexual exploitation of children by adult offenders. The Canadian Journal of Human Sexuality, 6, 285295. 
Table I

Descriptive research on the modus operandi of sexual offenders against children

\begin{tabular}{|c|c|c|c|}
\hline Study & Sample characteristics & $n$ & $\begin{array}{l}\text { Modus operandi stage(s) } \\
\text { investigated }\end{array}$ \\
\hline Berliner and Conte (1990) & $\begin{array}{l}\text { Child victims of sexual abuse } \\
\text { recruited from the Sexual Assault } \\
\text { Center in Seattle (USA) }\end{array}$ & 23 & $\begin{array}{l}\text { Gaining cooperation and keeping } \\
\text { the victim silent }\end{array}$ \\
\hline Budin and Johnson (1989) & $\begin{array}{l}\text { Incarcerated adult offenders } \\
\text { (USA) }\end{array}$ & 72 & $\begin{array}{l}\text { Gaining access to victim, trust, } \\
\text { and keeping the victim silent }\end{array}$ \\
\hline $\begin{array}{l}\text { Christiansen and Blake } \\
\text { (1990) }\end{array}$ & $\begin{array}{l}\text { Adult incest offenders following } \\
\text { treatment (USA) }\end{array}$ & ? & $\begin{array}{l}\text { Gaining trust, cooperation and } \\
\text { keeping the victim silent }\end{array}$ \\
\hline Conte et al. (1989) & $\begin{array}{l}\text { Adult offenders following } \\
\text { treatment and recruited at the } \\
\text { Northwest Treatment Associates- } \\
\text { Mercer in Seattle (USA) }\end{array}$ & 20 & $\begin{array}{l}\text { Gaining access to victim and } \\
\text { cooperation }\end{array}$ \\
\hline Elliott et al. (1995) & $\begin{array}{l}\text { Treated adult offenders recruited } \\
\text { from treatment programs, } \\
\text { probation, special hospitals, and } \\
\text { prisons (England) }\end{array}$ & 91 & $\begin{array}{l}\text { Gaining access to victim, trust, } \\
\text { cooperation, and keeping the } \\
\text { victim silent }\end{array}$ \\
\hline Kaufman, Orts et al. (1996) & $\begin{array}{l}\text { Adolescent and adult offenders } \\
\text { following treatment in five states } \\
\text { (USA) }\end{array}$ & 140 & Gaining cooperation \\
\hline $\begin{array}{l}\text { Kaufman, Wallace, Johnson } \\
\text { and Reeder (1995) }\end{array}$ & Victims' reports of abuse (USA) & 106 & Gaining cooperation \\
\hline Lang and Frenzel (1988) & $\begin{array}{l}\text { Adult offenders following } \\
\text { treatment in the Sex Offender } \\
\text { Program at Alberta Hospital } \\
\text { Edmonton (Canada) }\end{array}$ & 102 & $\begin{array}{l}\text { Gaining cooperation and keeping } \\
\text { the victim silent }\end{array}$ \\
\hline Leclerc et al. (2005) & $\begin{array}{l}\text { Adult offenders following } \\
\text { treatment and recruited from } \\
\text { prisons, probation and } \\
\text { penitentiary settings, parole } \\
\text { offices and treatment programs in } \\
\text { Quebec (Canada) }\end{array}$ & 23 & $\begin{array}{l}\text { Gaining trust, cooperation and } \\
\text { keeping the victim silent }\end{array}$ \\
\hline Proulx et al. (1995) & $\begin{array}{l}\text { Incarcerated adult offenders in } \\
\text { Quebec (Canada) }\end{array}$ & 10 & Gaining cooperation \\
\hline $\begin{array}{l}\text { Smallbone and Wortley } \\
(2000)\end{array}$ & $\begin{array}{l}\text { Incarcerated adult offenders in } \\
\text { Queensland (Australia) }\end{array}$ & 182 & All modus operandi stages \\
\hline van Dam (1996; 2001) & $\begin{array}{l}\text { Adult offenders following } \\
\text { treatment and recruited at the } \\
\text { Northwest Treatment Associates } \\
\text { in Seattle (USA) }\end{array}$ & 21 & $\begin{array}{l}\text { Gaining access to victim, trust, } \\
\text { cooperation and keeping the } \\
\text { victim silent }\end{array}$ \\
\hline $\begin{array}{l}\text { Wortley and Smallbone } \\
\text { (2006) }\end{array}$ & $\begin{array}{l}\text { Incarcerated adult offenders in } \\
\text { Queensland (Australia) }\end{array}$ & 169 & $\begin{array}{l}\text { Gaining access to victim and } \\
\text { obtaining time alone with victim }\end{array}$ \\
\hline Young (1997) & $\begin{array}{l}\text { Child sexual assault case-files } \\
\text { from the Victim-Witness } \\
\text { Assistance Programme in } \\
\text { Windsor/Essex County, Ontario } \\
\text { (Canada) }\end{array}$ & 45 & $\begin{array}{l}\text { Gaining access to victim, trust, } \\
\text { and cooperation }\end{array}$ \\
\hline
\end{tabular}


Table II

Research linking modus operandi of sexual offenders against children with other characteristics

\begin{tabular}{|c|c|c|c|}
\hline Study & Sample characteristics & $n$ & $\begin{array}{l}\text { Characteristics related to modus } \\
\text { operandi }\end{array}$ \\
\hline Carter et al. (2002) & $\begin{array}{l}\text { Adolescent offenders following } \\
\text { treatment in six different states } \\
\text { (USA) }\end{array}$ & 247 & $\begin{array}{l}\text { Non deviant and deviant sexual } \\
\text { fantasies }\end{array}$ \\
\hline Carter et al. (2005) & $\begin{array}{l}\text { Adolescent and adult offenders } \\
\text { following treatment in six different } \\
\text { states (USA) }\end{array}$ & 228 & $\begin{array}{l}\text { Non deviant and deviant sexual } \\
\text { fantasies }\end{array}$ \\
\hline Hunter et al. (2000) & $\begin{array}{l}\text { Police investigative records of } \\
\text { incarcerated adolescent offenders at } \\
\text { the FBI Academy in Quantico, } \\
\text { Virginia (USA) }\end{array}$ & 126 & Victim's vulnerability \\
\hline $\begin{array}{l}\text { Kaufman, Hilliker and } \\
\text { Daleiden (1996) }\end{array}$ & $\begin{array}{l}\text { Adolescent offenders following } \\
\text { treatment and incarcerated in Ohio } \\
\text { (USA) }\end{array}$ & 179 & $\begin{array}{l}\text { Gender of victim, age of youngest } \\
\text { victim and offender-victim } \\
\text { relationship }\end{array}$ \\
\hline Kaufman et al. (1998) & $\begin{array}{l}\text { Adolescent and adult offenders } \\
\text { following treatment in Minnesota, } \\
\text { Ohio, Oregon, and Washington } \\
\text { (USA) }\end{array}$ & 228 & $\begin{array}{l}\text { Age of the offender (adolescent or } \\
\text { adult) and offender-victim } \\
\text { relationship }\end{array}$ \\
\hline Leclerc et al. (2006) & $\begin{array}{l}\text { Incarcerated adult offenders } \\
\text { assessed between } 1995 \text { and } 2000 \text { at } \\
\text { the Regional Reception Centre of } \\
\text { Ste-Anne-des-Plaines, Quebec } \\
\text { (Canada) }\end{array}$ & 226 & $\begin{array}{l}\text { Prior offending achievement, age } \\
\text { of the victim and deviant sexual } \\
\text { fantasies }\end{array}$ \\
\hline
\end{tabular}

